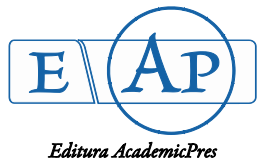

\title{
Morphological Variations in Caryopses and Seedlings of Two Grass Species of the Genus Dactyloctenium Willd.
}

\author{
Ajai Kumar SINGH*, Ayush Kumar SINGH, Manish Kumar SRIVASTAVA
}

Udai Pratap College (Autonomous), Department of Botany, Varanasi-221 002, India; ajaiupcollege@gmail.com ( ${ }^{*}$ corresponding author)

\begin{abstract}
Dactyloctenium aegyptium (L.) Willd. and D. aristatum Link. are common grass weeds of cultivated fields in many crops. The two grass weed species growing under similar habitat showed characteristic morphological differences of caryopses and seedlings. The identification of weeds at seedling stage may be useful in weed and environment management. Under the light microscopy, features like colour, base, surface, scutellum and hilum of caryopses showed differences between the studied species. $D$. aegyptium had dark brown caryopses colour, while $D$. aristatum had grey colour. The base of $D$. aegyptium was truncate, while $D$. aristatum had obtuse base. Both species had rugose surface, but in $D$. aegyptium surface undulations were closely spaced, whereas in D. Aristatum they were widely spaced. Similarly seedlings were found distinct with respect to coleoptile shape and size, first leaf sheath surface and first leaf blade shape and surface. D. aegyptium had oblong coleoptile, whereas it was obovate in D. aristatum. The leaf sheath and leaf blade were recorded glabrous and hairy in D. aegyptium and in $D$. aristatum respectively. Both species showed remarkable differentiations in their characters, thus indicating that the morphological attributes of caryopses and seedling can be exploited taxonomically and for crop and weed management.
\end{abstract}

Keywords: caryopses, Dactyloctenium aegyptium, Dactyloctenium aristatum, grass, seedling

\section{Introduction}

Seed and seedling traits are known to vary strongly across the tropical forest biome in order to cope up with the variations in the distribution and amount of rainfall, light, temperature and soil nutrient regimes. Seedlings of monocots are much more diverse than those of angiosperms, often with much derived characters. Sometimes, this makes morphological interpretation difficult (Tillich, 2007).

Seeds are also important for species identification based on diagnostic features. The seed coat is the outer covering of every mature seed. It is therefore the main modulator of interactions between the internal structure of the seed and the external environment (De Souza and Júlio, 2001).

Caryopsis morphology, as a reliable approach for assessing phylogenetic relationship, had been recognized in Poaceae (Bogdan, 1966; Barthlott, 1981; Wang et al., 1986; Liu et al., 2005). A study revealed that 7 subfamilies corresponded to 7 caryopsis subtypes for Chinese grasses (Wang et al., 1986). In another example, the caryopsis ventral face and embryo shape were valuable characters for recognizing three suprageneric groups in the gramineous subfamily Chloridoideae (Liu et al., 2005). In addition caryopsis shape, dimensions, colour, outline in cross section and surface features were valuable attributes for differentiating 44 species of Indian Eragrostis (Vivek et al., 2015). This is also supported by Hilu and Wright (1982), Terrel and Peterson (1993), Osman et al. (2012) and Gandhi et al. (2016).

Identification of weeds at seedling stage may be useful in weed management with respect to application of weedicides and environment management. In any integrated pest management program, the first logical step is to recognize the pest. Control measures depend upon accurate identification. Grasses occurring as weeds are difficult to identify in their vegetative stages, particularly in the one- to two-leaf (Singh and Singh 2015; Singh et al., 2015; Singh and Singh, 1994). At this stage it is important for crop management decisions. Many grasses do not flower until late in the growing season, after they have already had an impact on crop yields. Accurate identification is also important in the early growth stages because smaller grasses are easier to control with conventional management tactics than larger grasses. Smaller grass seedlings are more susceptible to lower dosages of herbicides, and thus greater control can be achieved while minimizing control costs (Bradley and Fishel, 2010).

According to Paria (2014) weed control prefers to focus on the youngest stages of the weeds. Gandhi et al. (2016) 
302

also advocated the same and opined that recognition of plants by their vegetative characters is essential in the development of a sound pasture-improvement programme. The morpho-taxonomic significance of grass seedlings is not much attempted. In the past, very little contributions have been made in this regard (Singh and Singh, 1994; Singh et al., 2015; Gandhi et al., 2016; Singh et al., 2016).

The genus Dactyloctenium Willd. belongs to the family Poaceae (subfamily: Chloridoideae, tribe: Cynodonteae and subtribe: Eleusininae). Its name originated from the Greek daktylos (finger) and ktenion (a little comb), alluding to the digitate inflorescences with pectinate spikelets. As per Mallett (2005), Dactyloctenium Willd. is represented by 14 species, distributed in Africa, Australasia, Europe, North America, Pacific, Temperate Asia, Tropical Asia and South America. In India it is represented by 4 species (Moulik, 1997 ) and by 3 species in Uttar Pradesh, India (Uniyal et al., 1994).

In the present study, two grass species (Dactyloctenium aegyptium and $D$. aristatum) of the same genus Dactyloctenium Willd., growing in the same habitat, have been evaluated for morphological features of caryopses and seedlings and their taxonomic significance.

\section{Materials and Methods}

The reported plant specimens were collected from Ahraura $\left(25.02^{\circ} \mathrm{N} 83.02^{\circ} \mathrm{E}\right.$, msl $\left.87 \mathrm{~m}\right)$, Mirzapur District, Vindhyan Region, Uttar Pradesh, India.

The two grass weed species (Dactyloctenium aegyptium and $D$. aristatum) are found commonly in the cultivated fields of the area. They were also found on road sides and on rocks. Collected specimens were dissected and identified with the help of different floras (Moulik, 1997; Singh, 2007). Identified species were further confirmed from Herbarium, Botanical Survey of India (Central Regional Centre, BSA), Allahabad, Uttar Pradesh, India. Voucher specimens have been deposited in the Herbarium, Department of Botany, Udai Pratap College (Autonomous), Varanasi, India.

\section{Caryopses morphology}

Caryopses were collected from mature spikelets. Mature caryopses were manually separated from the spikelets and used for the microscopic studies. Samples of 15-20 dried caryopses for each species were examined under Stereo Microscope (Olympus-Magnus MSZ-TR), photographed and described following Gandhi et al. (2016).

\section{Seedling morphology}

For the morphological observations on seedlings, caryopses have been grown in petri dishes $(20 \times 5 \mathrm{~cm})$ on moist filter paper at $22-24{ }^{\circ} \mathrm{C}$ in permanent light and in sandy soil in the green house and described as per Singh et al. (2016). Morphological features of mature specimens along with differentiation at mature and at seedling stage (Table 1) and illustrations (Fig. 1 and Fig. 2) have also been provided.

\section{Results}

The salient comparative morphological features observed in Dactyloctenium aegyptium and D. aristatum are represented in Fig. 1, Fig. 2 and Table 1.

A detailed description of caryopses and seedlings of reported taxa is given below along with description of mature plant.

Dactyloctenium aegyptium ( L.) Willd. Enum.

Hort. Berol. 1029. 1809. Boiss., H. Or. 5:556.

1884; Bor, Fl. Assam 5:110. 1940; Bor, Grasses

Burma Ceyl. Ind. Pak. 489. 1960. (Fig. 1, Fig. 2).

Dactyloctenium aegyptium is a annual grass, with fibrous roots, dull white, densely tufted, $5.0-7.0 \mathrm{~cm}$ long. Nodes are dark green, glabrous, slightly swollen. The leaf sheath is light green, membranous, compressed, hairy at mouth. The collar is light green, hairy. The ligule is oblong, membranous, base and apex truncate, margins ciliate, $0.1 \mathrm{~cm}$ long. The leaf blade is lanceolate, $7.0 \times 0.5 \mathrm{~cm}$, mean Length/Width ratio $(\mathrm{L} / \mathrm{W})$ is 14 , base truncate, apex acuminate, margins membranous, scabrid, hairy only at base, green, membranous, scabrous. Venation is parallelodromous; multicostate reticulate, 9 veins distinct. Prophyllum is lanceolate, $1.0 \times 0.20 \mathrm{~cm}$, mean $\mathrm{L} / \mathrm{W}$ is 5 , base truncate, apex unequally bifid, margins hyaline, transparent, glabrous, enrolled, light green, membranous, glabrous, binerved; nerves green, distinct and winged, wings hyaline, scabrous. The inflorescence is spike; spikes linear, digitate, compact, green, 3-6 in number, $5-6 \mathrm{~cm}$ long. The rachis is green, triquetrous, scabrid. Spikelets are broadly ovate, $0.30 \times 0.20$ $\mathrm{cm}$, mean L/W 1.5, base and apex rounded, green, glabrous,

Table 1. The characters differentiation of mature plants, caryopsis and seedlings of Dactyloctenium aegyptium and D. aristatum

\begin{tabular}{|c|c|c|c|}
\hline \multirow{2}{*}{ Sr.N. } & \multicolumn{3}{|c|}{ Mature plant } \\
\hline & Attributes & D. aegyptium & D. aristatum \\
\hline 1. & Height & $40-50 \mathrm{~cm}$ & $20-30 \mathrm{~cm}$ \\
\hline 2. & Leaf sheath & Glabrous & Hairy \\
\hline 3. & Prophyllum & $1.0 \mathrm{~cm}$ long & $1.5 \mathrm{~cm}$ long \\
\hline 4. & Ligule & $0.1 \mathrm{~cm}$ long & $0.3 \mathrm{~cm}$ long \\
\hline 5. & Number of spikes & $4-6$ & $1-2$ \\
\hline 6. & $\begin{array}{l}\text { Number of florets in } \\
\text { spikelets spikelet }\end{array}$ & $5-6$ & $2-4$ \\
\hline 7. & Lower glume & Lanceolate & Oblong \\
\hline 8. & Upper glume & With Awn & Without Awn \\
\hline \multicolumn{4}{|c|}{ Caryopsis } \\
\hline 1. & Colour & Dark brown & Gray \\
\hline 2. & Base & Truncate & Obtuse \\
\hline 3. & Surface & Widely rugose & Narrowly rugose \\
\hline 4. & Scutellum & $0.10 \mathrm{~cm}$ long & $0.05 \mathrm{~cm}$ long \\
\hline 4. & Hilum & Oval & Circular \\
\hline \multicolumn{4}{|c|}{ Seedlings } \\
\hline 1. & Coleoptile & Oblong & Obovate \\
\hline 2. & First leaf sheath & Glabrous & Hairy \\
\hline 3. & First leaf blade & $\begin{array}{l}\text { Obovate, } \\
\text { glabrous }\end{array}$ & $\begin{array}{l}\text { Elliptical, } \\
\text { hairy }\end{array}$ \\
\hline
\end{tabular}




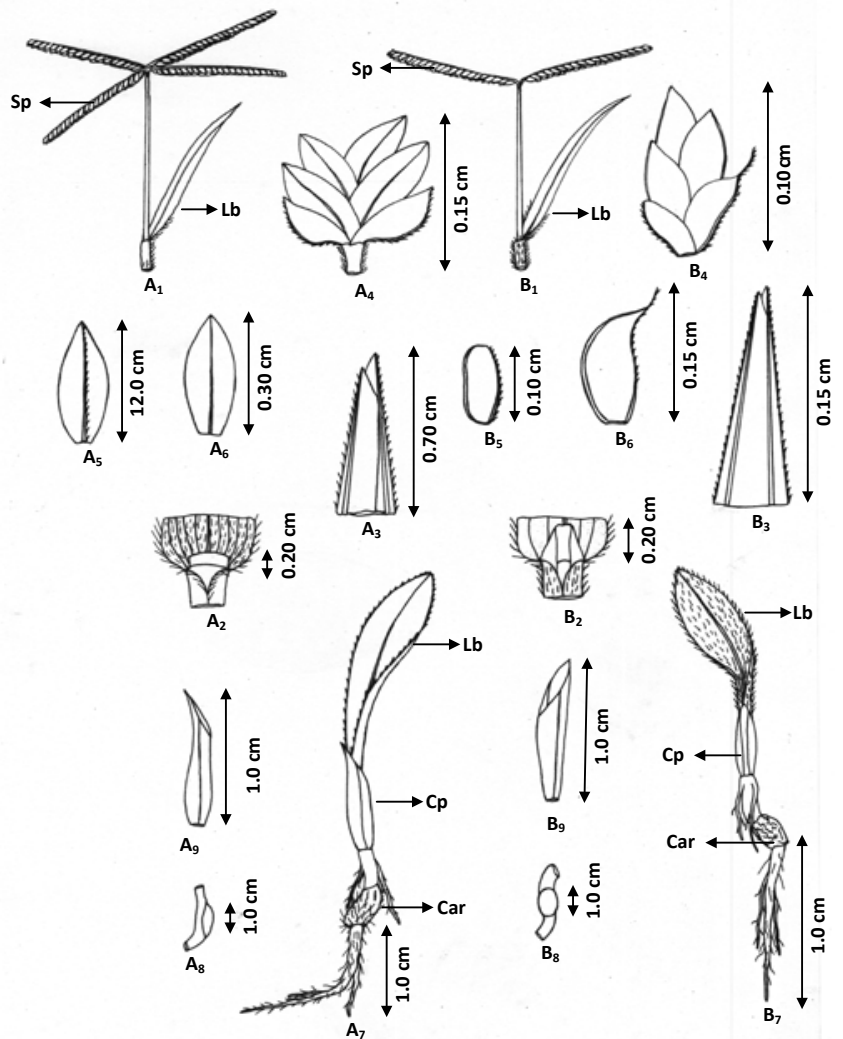

Fig. 1. (Original) A: Dactyloctenium aegyptium: $A_{1}$-Plant twig, $A_{2}$-Ligule, $A_{3}$-Prophyllum, $A_{4}$-Spikelet, $A_{5}$-Lower glume, $A_{6}$ Upper glume, $A_{7}$-Seedling, $A_{8}$-Scutelum, $A_{9}$-Coleoptile. B: Dactyloctenium aristatum : $B_{1}$-Plant twig, $B_{2}$-Ligule, $B_{3}$-Prophyllum, $\mathrm{B}_{4}$-Spikelet, $\mathrm{B}_{5}$-Lower glume, $\mathrm{B}_{6}$-Upper glume, $\mathrm{B}_{7}$-Seedling, $\mathrm{B}_{8}$-Scutelum, $\mathrm{B}_{9}$-Coleoptile, Cp-Coleoptile, Car-Caryopsis, Lb-Leaf blade, Sp-Spikelet
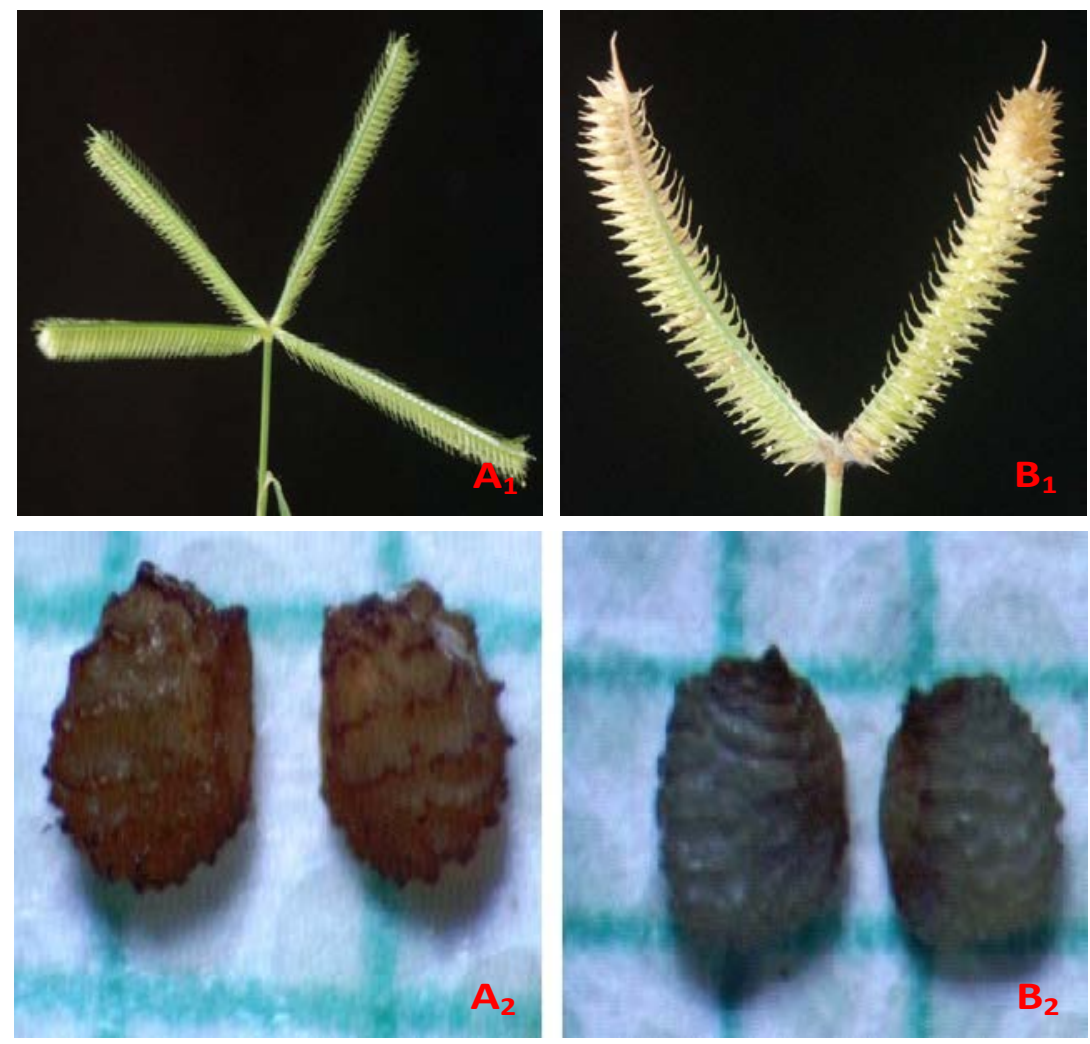

Fig. 2. The inflorescence and the caryopsis of Dactyloctenium aegyptium $\left(\mathrm{A}_{1}\right.$ and $\left.\mathrm{A}_{2}\right)$ and $D$. aristatum $\left(\mathrm{B}_{1}\right.$ and $\left.\mathrm{B}_{2}\right)$ 
subsessile with 3-7 florets. The lower glume is lanceolate, boat shaped $0.15 \times 0.5 \mathrm{~cm}$, mean L/W is 3 , base truncate, apex acute, margins entire, green, membranous, glabrous, single nerved; nerve green, distinct and scabrid. The upper glume is the same as lower glume but nerve glabrous. The lemma is ovate, $0.15 \times 0.10 \mathrm{~cm}$, mean $\mathrm{L} / \mathrm{W} 1.5$, base truncate, apex obtuse, margins and surface same as upper glume, trinerved; nerves green, distinct and glabrous. The palea is ovate, $0.10 \times 0.10 \mathrm{~cm}$, mean $\mathrm{L} / \mathrm{W} 1$, base truncate, apex bifid, margins hyaline, entire, binerved; nerves green, distinct, glabrous. The lodicules were absent. The stamens are 3; the anthers are dithecous, versatile, dorsifixed, elliptical, yellow, glabrous, $0.1 \mathrm{~cm}$ long. The ovary is ovate, glabrous, translucent, $0.05 \mathrm{~cm}$ long; styles 2, linear, terete, glabrous, $0.1 \mathrm{~cm}$ long ; the stigma was colourless, hairy; hair base broad, apex acute, arranged in two rows.

The caryopses is ovoid-quadrangular in outline, $0.07 \times$ $0.05 \mathrm{~cm}$, mean L/W 1.4, base truncate, apex rounded, and laterally compressed, reddish-brown, surface rugose with widely spaced undulations. The scutellum is ovate, $0.10 \times$ $0.05 \mathrm{~cm}$, mean L/W 2, base and apex rounded, flat and glabrous. The hilum is oval.

The seedling germination was mesogeal. The primary root was fibrous, branched, dull white, hairy; hair base broad, apex acute, transparent; $1.5 \mathrm{~cm}$ long at coleoptile stage, $2.0 \mathrm{~cm}, 2.5 \mathrm{~cm}$ and $3.0 \mathrm{~cm}$ long at $1^{\text {st }}, 2^{\text {nd }}$ and at $3^{\text {rd }}$ leaf stages respectively. The collet was distinct, dull white, swollen, hairy; hairs base broad, apex acute, transparent, 0.2 $\mathrm{cm}$ long. The epiblast was swollen, distinct with mesocotyl. The mesocotyl was light green, glabrous, terete, $0.5 \mathrm{~cm}$ long. The coleoptile was oblong, $0.90 \times 0.15 \mathrm{~cm}$, mean L/W 6.0, base truncate, apex acute, green, membranous, glabrous, binerved; nerves green, distinct, parallel. The adventitious roots were present at coleoptile stage. The first leaf sheath was green, membranous, glabrous and compressed, margins entire, hyaline, glabrous, $0.5 \mathrm{~cm}$ long. The ligule was membranous; base truncate, apex rounded, glabrous, $0.6 \mathrm{~cm}$ long. The first leaf blade was obovate, $1.8 \times 0.4 \mathrm{~cm}$, mean $\mathrm{L} / \mathrm{W}$ 4.5, base cuneate, apex obtuse, the margins were denticulate, green, membranous and glabrous, veins 5 . The second leaf sheath was green, membranous, enrolled, much compressed, glabrous, with entire margins, $0.6 \mathrm{~cm}$ long. The ligule was same as the first leaf. The second leaf blade was lanceolate, $2.5 \times 0.5 \mathrm{~cm}$, the mean $\mathrm{L} / \mathrm{W}$ was 5.0 , base truncate, apex acuminate, the margins and surface was same as first leaf, and 5 veins were present.

The common names of Dactyloctenium aegyptium are: beach wiregrass, crowfoot grass, coast button grass, comb fringe grass, duck grass, Durban crowfoot, Egyptian finger grass, Egyptian grass and it blooms during May-October.

Dactyloctenium aegyptium is distributed in North Kenya to Sudan, and eastwards through Arabia to India, Pakistan.

Dactyloctenium aristatum Link. Hort. Berol. 1: 59.

1827. Bor, Grasses Burma Ceyl. Ind. Pak. 489. 1960;

Bor in Rech.f., Fl. Iran. 70: 439. 1970. (Fig. 1, Fig. 2).

Dactyloctenium aristatum is a annual grass, with fibrous roots, dull white, tufted, $4.0-6.0 \mathrm{~cm}$ long. The nodes are green, glabrous, swollen. The leaf sheath is light green, membranous, compressed, tuberculate-hairy. The collar is light green, hairy. The ligule is membranous, base truncate, apex rounded, entire, $0.3 \mathrm{~cm}$ long. The leaf blade is lanceolate, $6.0 \times 0.4 \mathrm{~cm}$, the mean $\mathrm{L} / \mathrm{W}$ is 15 with truncate base and acuminate apex, margins membranous, scabrid, hairy only at base, green, membranous, venation parallelodromous; multicostate reticulate, veins- 5 . The prophyllum is lanceolate, $1.5 \times 0.20 \mathrm{~cm}$, the mean $\mathrm{L} / \mathrm{W}$ is 7.5, base truncate, apex bifid, margins hyaline and enrolled, membranous, glabrous, binerved; the nerves are green, distinct and winged; wings hyaline, scabrous. The inflorescence is spike; spikes oblong, digitate, compact, green, $1-2$ in number, $3-4 \mathrm{~cm}$ long. The rachis is green, triquetrous, scabrid. The spikelets are broadly ovate, $0.40 \mathrm{x}$ $0.20 \mathrm{~cm}$, the mean $\mathrm{L} / \mathrm{W}$ is 2 , base and apex rounded, green, glabrous, sessile with 2-3 florets. The lower glume is oblong, $0.2 \times 0.1 \mathrm{~cm}$, the mean $\mathrm{L} / \mathrm{W}$ is 2 , base truncate, apex acute, margins entire, green, membranous, glabrous, 1-nerved; nerve green, distinct, scabrid. The upper glume is oblong, $0.25 \times 0.1 \mathrm{~cm}$, the mean $\mathrm{L} / \mathrm{W}$ is 2.5 , base and apex truncate, margins and surface same as lower glume except nerves; nerves green, distinct, scabrid, extended into curved awn; awn green, scabrid, $0.15 \mathrm{~cm}$ long. The lemma is ovate, $0.3 \mathrm{x}$ $0.15 \mathrm{~cm}$, mean L/W is 2 , base truncate, apex obtuse, margins and surface same as upper glume, single nerved; nerve green, distinct, extended into mucro; mucro green, glabrous, $0.1 \mathrm{~cm}$ long. The palea is elliptical, $0.25 \times 0.10 \mathrm{~cm}$, the mean $\mathrm{L} / \mathrm{W}$ is 2.5 , base truncate, apex bifid, margins hyaline, entire, surface same as lemma, binerved; nerves green, distinct, scabrous, ending at apex. The lodicules are obovate, $0.05 \times 0.04 \mathrm{~cm}$, the mean $\mathrm{L} / \mathrm{W}$ is 1.2 , base rounded, apex truncate, dull white and glabrous. The stamens were three with dithecous anthers, versatile, dorsifixed, ovate, dull white, glabrous, $0.1 \mathrm{~cm}$ long. The ovary was ovate, glabrous, translucent, $0.05 \mathrm{~cm}$ long; styles 2, linear, terete, glabrous, $0.1 \mathrm{~cm}$ long; the stigma was colourless, hairy; hairs in two rows, base broad and with acute apex.

The caryopses is ovoid-quadrangular in outline, $0.1 \mathrm{x}$ $0.08 \mathrm{~cm}$, the mean $\mathrm{L} / \mathrm{W}$ is 1.2 , base obtuse, apex rounded, laterally compressed, gray in colour, surface rugose with narrowly spaced undulations. The scutellum is ovate, $0.05 \mathrm{x}$ $0.03 \mathrm{~cm}$, mean L/W 1.6, base and apex rounded, flat and glabrous. The hilum is oval.

The seedling germination was mesogeal. The primary roots were fibrous, branched, dull white, terete, $1.5 \mathrm{~cm}$ long at coleoptile stage, $2.0 \mathrm{~cm}, 2.5 \mathrm{~cm}$ and $3.0 \mathrm{~cm}$ long at $1^{\text {st }}, 2^{\text {nd }}$ and at $3^{\text {rd }}$ leaf stages respectively. The collet was dull white, slightly swollen, hairy; hair base broad, apex acute, transparent, $0.2 \mathrm{~cm}$ long. The epiblast was slightly swollen, surface undulate, dull white, glabrous. The mesocotyl was light green, glabrous, terete, $0.6 \mathrm{~cm}$ long. The coleoptile was obovate, $1.0 \times 0.2 \mathrm{~cm}$, the mean $\mathrm{L} / \mathrm{W}$ was 5.0 , base truncate, apex acute, green, membranous, glabrous, binerved; nerves green, distinct, and parallel. The adventitious roots was present at coleoptile stage. The first leaf sheath was green, membranous, hairy; hair base broad, apex acute, transparent, $0.2 \mathrm{~cm}$ long; margins entire, $0.5 \mathrm{~cm}$ long. The ligule was present at $2^{\text {nd }}$ leaf stage. The first leaf blade was elliptical, $0.6 \times 0.3 \mathrm{~cm}$, the mean $\mathrm{L} / \mathrm{W}$ was 2 , base cuneate, apex acute, margins denticulate, green, pubescent; hairs as on leaf sheath; veins 7 . The second leaf sheath was same as the first leaf. The ligule was membranous, base truncate, apex obtuse, margins entire, $0.2 \mathrm{~cm}$ long. The second leaf blade was oblong, $1.0 \times 0.4 \mathrm{~cm}$, the mean $\mathrm{L} / \mathrm{W}$ was 2.5 , base cuneate, apex acute, the margins and the surface was same as the first leaf blade with 7 veins. 
Dactylocteniumaristatum is distribuited inNorth Kenya to Sudan and east wards through Arabia to India and Pakistan and it blooms during September-November.

\section{Discussion}

\section{Caryopses features}

Light microscopic features of $D$. aegyptium and $D$. aristatum revealed few similar features. Both are ovoid quadrangular in shape. They had ovate scutellum, belong to the small type of embryo (embryo \% was less than 46\%). Both species showed ovate scutellum but differ with respect to length. A marked difference was noted in the colour base, surface and hilum of the two species as $D$. aegyptium had dark brown colour, while $D$. aristatum had grey colour. The base of $D$. aegyptium was truncate, while $D$. aristatum had obtuse base. Both the taxa had rugose surface but in $D$. aegyptium surface undulations were closely spaced whereas in $D$. aristatum it was widely spaced. The hilum was found distinct in shape i.e. oval and circular in D. aegyptium and $D$. aristatum respectively (Fig 2, Table 1). Liu et al. (2005) also studied and revealed that caryopsis morphology in Chlorideae is significant. The current observations were found similar to Zhang et al. (2014). The authors reported that caryopsis shapes, embryo proportions, and sculpturing patterns were valuable diagnostic characters at the interspecific level in Themeda. In a recently study, Vivek et al. (2015) observed the caryopsis morphology of Ergrostis in India representing 44 species and reported their morphological significance. Similar observations have been made by many workers. Hilu and Wright (1982) discussed phylogenetic relationship of tribe Chlorideae, mainly on the basis of morphological and molecular data. Terrel and Peterson (1993) studied the caryopsis morphology of tribe Triticeae to evaluate the morphological structure of the caryopses within Triticeae and divided the tribe into two major subtribes. Osman et al. (2012) studied the fruit morphology of 33 annual grass species from Egypt belonging to 24 genera and 11 tribes. Gandhi et al. (2016) published a book on the identification and characterization of caryopsis and seedlings.

\section{Seedlings features}

The seedling morphology of reported grass weed taxa showed some interesting diagnostic attributes viz. coleoptile, First leaf sheath and First leaf blade (Fig 1A, 1B; Table 1). On the basis of these attributes the reported taxa $D$. aegyptium and $D$. aristatum can be easily differentiated and identified at seedling stage. However, they were also clearly distinct at maturity with respect to leaf sheath, prophyllum, ligule, number of spikes, number of florets in spikelets, lower glume and upper glume (Fig 1A, 1B, Fig $2 \mathrm{~A}_{1}, 2 \mathrm{~B}_{1}$, Table 1). The coleoptile shape, and the shape and surface of first leaf sheath and first leaf blade of the reported taxa showed clear cut distinction and these attributes are found significant. As it is evident from Fig. $1 \mathrm{~A}_{9}, 1 \mathrm{~B} 9$ and Table 1, D. aegyptium had oblong coleoptile whereas it was obovate in $D$. aristatum. Similarly leaf sheath and leaf blade were recorded glabrous and hairy in $D$. aegyptium and in $D$. aristatum respectively. The shape of the first leaf blade was obovate and elliptical in D. aegyptium and D. aristatum respectively (Fig. $1 \mathrm{~A}_{7}, 1 \mathrm{~B}_{7}$, Table 1 ). The previous observations on this line by Kuwabara (1960, 1961), JianGuo et al. (1993), Singh and Singh (1994); Durgan (1999); Wintel et al. (2009); Harries (2010); Singh et al. (2015); Singh and Singh (2015); Gandhi et al. (2016) and Singh et al. (2016) are found supportive in the sense of present observation.

\section{Conclusions}

The caryopsis and the seedling morphological characters were valuable diagnostic characters at the interspecific level and morphological attributes of grass. The caryopsis and seedlings of $D$. aegyptium and $D$. aristatum can be exploited from taxonomic point of view and for crop weed management.

\section{Acknowledgements}

Thanks are due to University Grants Commission, New Delhi for financial support [Project File No. 43-96/2014 (SR)].

\section{References}

Barthlott WG (1981). Epidermal and seed surface characters of plants: systematic applicability and some evolutionary aspects. Nordic Journal of Botany 1(3):345-355.

Bogdan AV (1966). Seed morphology of some cultivated African grasses. Proceedings of the International Seed Testing Association 31:789-799.

Bradley KW, Fishel F (2010). Integrated pest management: identifying grass seedlings. Extension Publications, 2800, Maguire Blvd. Columbia

De Souza FH, Júlio M (2001). The seed coat as a modulator of seedenvironment relationships in Fabaceae. The Brazilian Journal of Botany 24(4):365-375.

Durgan B (1999). Broadleaf and grass weed seedling identification keys. Communication and educational technology services, University of Minnesota Extension.

Gandhi D, Albert S, Pandya N (2016). Handbook on the morphology of common grasses: identification and characterization of caryopsis and seedlings. Apple Academic Press Inc., NJ, USA.

Harries WF (2010). The identification of some of the more common native Oklahoma grasses by vegetative characters. Oklahoma Native Record, Vol 10.

Hilu KW, Wright K (1982). Systematics of Gramineae: A cluster analysis study. Taxon 31:9-36.

Jian-Guo H, Clifford HT, Jia Shen-Xiu WP (1993). A cluster analysis of seedling characters of Gramineae. Acta Phytotaxonomica Sinica 31(6):517-532

Kuwabara $Y(1960)$. The first seedling leaf in grass systematic. Journal of Japanese Botany 35:139-145.

Kuwabara Y (1961). On the shape and direction of leaves of grass 
306 seedlings. Journal of Japanese Botany 36:368-373.

Liu Q, Zhao NX, Hao G, Hu XY, Liu YX (2005). Caryopsis morphology of the Chloridoideae (Gramineae) and its systematic implications. Botanical Journal of Linnean Society 148:57-72.

Mallett K (2005). Flora of Australia-Poaceae 3, Vol. 44B. ABRS, Canberra/CSIRO Publishing, Melborne, Australia.

Moulik S (1997). Grasses and bamboos of India. Vol. 1 \& 2. Scientific Publishers (India),Jodhpur.

Osman AK, Mohammed AZ, Hamed ST, Hussein NR (2012). Fruit morphology of annual grasses from Egypt. Asian Journal of Plant Sciences 11(6):268-284.

Paria ND (2014). Botanical research in India in the domain of seedling morphology in relation to taxonomy. Science and Culture 80(910):262-270.

Singh AK (2016). Sedges and grasses of Eastern Uttar Pradesh. Vol. 1\&2. Daya Publishing House, Delhi.

Singh AK, Sahu RK, Singh AK (2015). Morpho-taxonomic distinction between Oryza rufipogon and Oryza sativa (Poaceae) at seedling stage. Annals of Plant Sciences 4(04):1068-1071.

Singh AK, Singh AK (2015). On the seedling morphology of some grass weeds-Echinochloa P. Beauv. (Poaceae). Indian Journal of Forestry 38(1):47-50.

Singh AK, Singh AK, Srivastava MK (2016). Taxonomy and seedling morphology of six species of Digitaria (Poaceae) from Vindhyan region, Uttar Pradesh, India. International Journal of Advanced Research 4(8):464-472.
Singh PK, Singh SK (1994). On the identification of seeds and seedlings of Poaceous crop weeds of Gorakhpur division. Journal of Living World 1(2):180-183.

Terrel EE, Peterson PM (1993). Caryopsis morphology and classification in the Triticeae (Pooideae: Poaceae). Smithsonian Contribution to Botany 83:1-25.

Tillich HJ (2007). Seedling diversity and the homologies of seedling organs in the order Poales (Monocotyledons). Annals of Botany 100(7):1413-1429.

Uniyal BP, Balodi B, Nath B (1994). The grasses of Uttar Pradesh-A checklist. Bishen Singh Mahendra Pal Singh, Dehra Dun, Indai.

Vivek CP, Murthy GVS, Gnanasekaran G, Kabeer KAA, Nair VJ (2015). A study on the caryopses morphology of the grass genus Eragrostis in India. Nelumbo 57:1-10.

Wang SJ, Guo PC, Li JH (1986). The major types of caryopses of the Chinese Gramineae in relation to systematics. Acta Phytotaxonomica Sinica 24:327-345.

Wintel B, Moore G, Nicholas P (2009). Identifying sub-tropical grass seedlings. Bulletin No 4775, Department of Agriculture and Food, Western Australia, South Perth, Australia.

Zhang Y, Xiaoying H, Yunxiao L, Qing L (2014). Caryopsis micromorphological survey of the genus Themeda (Poaceae) and allied spathaceous genera in the Andropogoneae. Turkish Journal of Botany 38:665-676. 